\title{
FE DE ERRATUM
}

En el número de Febrero de 2006 de la Revista Médica de Chile, volumen 134, páginas 167-173, en el artículo "Complicaciones asociadas a la trombocitopenia profunda en pacientes con dengue", de los autores Fredi Alexander Díaz-Quijano, Luis Ángel Villar-Centeno y Ruth Aralí Martínez-Vega:

En la Tabla 2 dice: $1-1,78^{*}$

Debe decir: $\quad 1-1,78+$

En página 172, tercer párrafo, dice: (Tablas 3 y 4).

Debe decir:

(Tablas 4 y 5)

En referencia 21 dice: en prensa.

Debe decir:

21. Díaz-Quijano FA; Martínez-Vega RA, Villar-Centeno LA. Indicadores tempranos de severidad en Dengue. Enferm Infecc Microbiol Clin 2005; 23:529-32. 